\title{
Nematicidal Activity of Plant Extracts Against the Root-Knot Nematode, Meloidogyne incognita
}

\author{
Wiratno*,a,b $^{*}$ D. Taniwiryono ${ }^{\mathrm{c}}$, H. Van den Berg ${ }^{\mathrm{b}}$, J.A.G. Riksen ${ }^{\text {d }}$, I.M.C.M. Rietjens ${ }^{\mathrm{b}}$, \\ S.R. Djiwanti ${ }^{\mathrm{a}}$, J.E. Kammenga ${ }^{\mathrm{d}}$ and A.J. Murk ${ }^{\mathrm{b}}$ \\ ${ }^{a}$ Indonesian Medicinal and Aromatic Crops Research Institute, Jl. Tentara Pelajar No. 3, Bogor, Indonesia \\ ${ }^{b}$ Section Toxicology, Wageningen University, Postbus 8000, 6700 EA Wageningen, The Netherlands \\ ${ }^{c}$ Indonesian Biotechnology Research Institute for Estate Crops, Jl. Taman Kencana No. 1, Bogor, Indonesia \\ ${ }^{d}$ Laboratory of Nematology, Wageningen University, P.O. Box 8123, 6709 ES Wageningen, The Netherlands
}

\begin{abstract}
Nematicidal activity of extracts from plants was assayed against Meloidogyne incognita. In laboratory assays extracts from tobacco (Nicotiana tabacum L), clove (Syzygium aromaticum L), betelvine (Piper betle $\mathrm{L}$ ), and sweet flag (Acorus calamus $\mathrm{L}$ ) were most effective in killing the nematode, with an $\mathrm{EC}_{50}$ that was 5-10 times lower than the $\mathrm{EC}_{50}$ of the synthetic pesticides chlorpyrifos, carbosulfan and deltamethrin. The shapes of the dead nematodes differed in a characteristic way, and groups of pesticides and plant extracts could clearly be distinguished based on this phenomenon, which may be an indicator for the modes of action of the tested pesticides. In a greenhouse bioassay clove bud and betelvine were tested as mulch. Experiments revealed that the total number of live nematodes on roots of pepper plants treated with mulch of the clove bud was $7 \%$ of that of the controls and did not differ significantly from that of plants treated with the recommended synthetic pesticide carbofuran. The application of clove buds as a botanical pesticide for future use against nematodes is highly promising since clove is the $6^{\text {th }}$ major plant grown on Bangka Island, and the market value of clove has decreased sharply over the last years.
\end{abstract}

Keywords: Black pepper, botanical nematicide, clove, mode of action.

\section{INTRODUCTION}

Root-knot nematode, Meloidogyne incognita Kofoid and White (Chitwood) (Tylenchida: Heteroderidae) is a major plant-parasitic nematode species affecting the quantity and quality of the crop production in many annual and perennial crops. Infected plants show typical symptoms including root galling, stunting and nutrient deficiency, particularly nitrogen deficiency [1]. On Bangka Island, South of Sumatra, Indonesia, this nematode is considered to be one of the major problems in black pepper cultivation. In 2003, 4.900 ha of the total of 52.468 ha of pepper plantations was severely infected by this pest [2]. Although, there is no information about the exact impact of nematode infection on the loss of pepper production, it is clear from visible inspection that severely attacked plants have a reduced vitality, which produce less fruits, and finally will die. Davis and May [3] informed that the yield losses of cotton production caused by M. incognita in 2002 were estimated to be between 18.0$47.3 \%$. Therefore the presence of this pest in plantations has to be controlled.

The population of plant-parasitic nematodes in the field can be minimized through several approaches such as using natural enemies [4, 5], enhancing cultural practices [6], cultivating resistant cultivars [7], and applying pesticides [8].

*Address correspondence to this author at the Indonesian Medicinal and Aromatic Crops Research Institute, Jl. Tentara Pelajar No. 3, Bogor, Indonesia; E-mail: wiratno02@yahoo.com
Since the 1950s, however, farmers have relied mainly on synthetic pesticides rather than on other approaches. This sometimes results in excessive and unsafe use of synthetic pesticides [9]. Therefore, it has become an important issue to find alternative control strategies, which are as effective as synthetic pesticides, safer to farmers, consumers, and the environment and relatively easily available at low price [10]. One of possible alternatives is the utilization of pesticides from plant origin, known as botanical pesticides [11]. These pesticides are generally considered to be non-persistent under field conditions as they are readily transformed by light, oxygen and microorganisms into less toxic products. Therefore no residues are expected on the products or in the environment [12].

The study reported in the present paper is part of a larger project in which 17 plant species were selected based on their availability and potential use as botanical pesticide, are tested for nematicidal activity. In the present study we evaluate the nematicidal potency of extracts from these 17 plant species, 15 of which may have nematicidal activity against $M$. incognita. The results are compared to those of three synthetic pesticides, namely chlorpyrifos (an organophosphate insecticide) [13], carbosulfan (a carbamate insecticide) [14] and deltamethrin (a pyrethroid insecticide) representing the three groups of often used or advised pesticides to control pests of the black pepper on Bangka Island [9]. The 2 most potent extracts are subsequently tested in a greenhouse experiment to evaluate effectiveness of their raw materials ap- 
plied as a mulch to control the nematode attacking roots of the pepper plant.

\section{MATERIALS AND METHODS}

\subsection{Chemicals}

The synthetic pesticides that were used in this study are chlorpyrifos $200 \mathrm{~g} \mathrm{l}^{-1}$, carbosulfan $200 \mathrm{~g} \mathrm{l}^{-1}$, deltamethrin 25 $\mathrm{g} \mathrm{l}^{-1}$, and carbofuran $3 \mathrm{G}$, purchased from the agro-chemical shop, Sarana Tani in Bogor, Indonesia. DMSO (99.9\% pure for spectroscopy from Acros Organics), was supplied by Sigma Aldrich (Zwijndrecht, The Netherlands), Tween 80 (synthesis grade), acetone (100\%, analysis grade) and ethanol (absolute, analysis grade) from Merck (Darmstadt, Germany) were supplied by VWR (Amsterdam, The Netherlands).

\subsection{Preparation of the Plant Extracts}

All plant materials were obtained from the experimental gardens of the Indonesian Medicinal and Aromatic Crops Research Institute (IMACRI) and extracted in the post harvest laboratory of the Institute. The 17 plant species and part of the plant used for extraction are presented in Table 1. The extraction procedures of the plant materials were based on the method described by Yuliani and Rusli [15]. In short $1 \mathrm{~kg}$ material was dried in the sun for 4-5 days then ground in a hammer mill (Reisch Mühle made by Karl Kolb (Dreieich, Germany)) using $3 \mathrm{~mm}$ grinders. To the $1 \mathrm{~kg}$ powder 51 of ethanol (96\%) was added followed by $3 \mathrm{~h}$ mixing at $500 \mathrm{rpm}$ using an electric mixer made by Karl Kolb (Dreieich, Germany). Subsequently, the mixture was left overnight in the dark at $28 \pm 1^{\circ} \mathrm{C}$ to allow further extraction of the active ingredients. After this, the mixture was filtered using Whatman no 91 filter paper and the residues were soaked and shaken again in 11 of ethanol for $2 \mathrm{~h}$. The solution was filtered again and the first and second filtrate were mixed and concentrated using a rotavapor at $45^{\circ} \mathrm{C}$ for approximately $3 \mathrm{~h}$ until all ethanol was removed. The extracts were transferred into brown glass bottles and stored at $-4^{\circ} \mathrm{C}$. Only cashew nut was treated differently as cashew nut shell liquid (CNSL) was prepared by pressing the shell of the cashew seed in a manual presser made by the post harvest division of the IMACRI, after which the liquid was collected and stored in a brown glass bottle. On the following week about $10 \mathrm{ml}$ of each extract were poured into $20 \mathrm{ml}$ of glass bottles and they were stored at $-20^{\circ} \mathrm{C}$ in the laboratory of Toxicology of Wageningen University until further use.

\subsection{Laboratory Exposure of Nematodes}

The laboratory experiment was conducted in triplicate in the Sub Department of Nematology, Wageningen University, the Netherlands. The tested nematode species, $M$. incognita, was harvested according to the method as described by Barker [16]. The roots of about 3 months old tomato plants, which had been infected with the nematode were washed in fresh tap water. After that the roots were cut into $1-2 \mathrm{~cm}$ length and put in a round filter container then gently placed in the funnel, which had been placed in a mist chamber. Ac-

Table 1. The Botanical Species and Plant Parts that were Extracted, the Yield (\%), and the Density of the Final Product

\begin{tabular}{|c|c|c|c|c|c|}
\hline Scientific Name & $\begin{array}{c}\text { Common } \\
\text { Names }\end{array}$ & $\begin{array}{c}\text { Part } \\
\text { Extracted }\end{array}$ & $\begin{array}{c}\text { Extraction } \\
\text { Rate }(\%)\end{array}$ & $\begin{array}{l}\text { Density } \\
\left(\mathrm{g} \mathrm{ml}^{-1}\right)\end{array}$ & References \\
\hline Syzygium aromaticum $\mathrm{L}^{*}$ & Clove & Bud & 22.2 & 0.91 & {$[18]$} \\
\hline Nicotiana tabacum $\mathrm{L}^{*}$ & Tobacco & Leaf & 8.1 & 1.07 & [19] \\
\hline Piper betle $\mathrm{L}^{*}$ & Betelvine & Leaf & 8.6 & 0.96 & {$[20]$} \\
\hline Chrysanthemum cinerarieaefolium $\mathrm{L}^{*}$ & Pyrethrum & Flower & 9.6 & 0.75 & {$[22]$} \\
\hline Cymbopogon nardus $\mathrm{L}^{*}$ & Citronella & Leaf, stem & 6.2 & 1.06 & {$[23]$} \\
\hline Derris elliptica Benth* & Tuba root & Root & 6.3 & 0.96 & {$[24]$} \\
\hline Azadirachta indica $\mathrm{L}^{*}$ & Neem & Seed & 5.1 & 1.61 & {$[25]$} \\
\hline Richinus communis $\mathrm{L}^{*}$ & Castor bean & Seed & 11.9 & 1.04 & [26] \\
\hline Annona muricata $L^{*}$ & Graviola & Seed & 9.6 & 0.85 & [27] \\
\hline Cymbopogon citratus $\mathrm{L}^{*}$ & Lemongrass & Leaf, stem & 9.5 & 0.86 & {$[28]$} \\
\hline Anacardium occidentale $\mathrm{L}^{*}$ & Cashew & Seed & 4.1 & 1.00 & {$[29,30]$} \\
\hline Pelargonium citrosa Van Leenii** & Citrosa & Leaf & 9.7 & 0.68 & [31] \\
\hline Pogostemon cablin Benth & Patchouli & Leaf & 12.4 & 0.89 & - \\
\hline Pachyrhizus erosus $\mathrm{L}$ & Yam bean & Seed & 5.0 & 0.94 & - \\
\hline
\end{tabular}

$*=$ known to contain nematicidal properties. $* *=$ predicted to have nematicidal effect. 
tive nematodes passed through the filter and sank to the bottom of the funnel stem. After 4 days nematodes could be harvested and used for the experiments. The average density of nematode juveniles in the suspension thus prepared was about $1750 \mathrm{ml}^{-1}$.

The pesticide stocks were made in $1 \mathrm{ml}$ glass vials by diluting the extracts in a solvent mixture of DMSO:Tween 80 : Acetone $=1: 2: 3$. In a first pilot study the maximum tolerated total solvent concentration was determined and this should not exceed 5\% to avoid unspecific toxicity. The test concentrations were made by adding $40 \mu 1$ of the plant extract or the synthetic pesticide stocks to $460 \mu \mathrm{l}$ of fresh tap water in a 12-well plate. The mixing-plate was gently shaken manually for about 2 min to allow the pesticides to mix properly. After that, $150 \mu \mathrm{l}$ of the solution was transferred into 24 well test plates. Next, $90 \mu \mathrm{l}$ of the nematode suspension containing approximately 150 juveniles was added into the wells and gently mixed for another 2 min and kept standing overnight at $24^{\circ} \mathrm{C}$. After $24 \mathrm{~h}$ the dead and alive nematodes were counted to evaluate the mortality rate. A second pilot study was performed to determine the rough toxicities of the pesticides in $5 \mathrm{mg}$ and $31.5 \mathrm{mg}$ of plant extract and technical mixture of synthetic pesticides $\mathrm{ml}^{-1}$ exposure medium, respectively. In these stock solutions, however, the visibility of the nematodes was not enough. Therefore the nematode solution was washed to make the nematodes completely visible. Washing was done by first adding $0.5 \mathrm{ml}$ of fresh water to the 24 well plates containing exposed nematodes, letting all nematodes settle again on the bottom of the well during $3 \mathrm{~min}$, and carefully removing $0.5 \mathrm{ml}$ again using a micro pipette. This procedure was repeated 3 times. In order to evaluate a possible recovery effect, the observation of the mortality of the nematodes was conducted twice during the pilot study. The first time was conducted immediately after washing for the second time of approximately $6 \mathrm{~h}$ after the first observation. The mortality of the treated nematodes was determined using a stereo microscope with 10-fold magnification. Nematodes were considered dead when no movement was observed during two seconds even after mechanical prodding. As no recovery of nematodes was observed, this was not further studied in the final experiment. Washing to dilute botanical extracts before counting the nematodes also was not needed, as in the pilot experiment the dead nematodes were found to have a specific shape, defined as either straight (I-shape), bent (banana-shape), sigmoid ( $\Sigma$-shape), and curly ( $\infty$-shape) which can be used to determine the death or live nematodes. In the final experiments all pesticides were tested in at least 5 concentrations including a solvent control. In order to make a comparison between botanical and synthetic nematicides, lethal concentrations i.e. $\mathrm{LC}_{20}, \mathrm{LC}_{50}$ and $\mathrm{LC}_{90}$, were expressed as mg applied extract or technical mixture $\mathrm{ml}^{-1}$ exposure medium because the nature and concentration of the active ingredients of the botanical extracts are unknown.

\subsection{Greenhouse Experiment}

The greenhouse experiment was conducted at The Indonesian Medicinal and Aromatic Crops Research Institute, Bogor. Nematodes for inocula were collected from the roots of pepper plants which were grown in the Botanical Garden of the Bangka Belitung Assessment Institute for Agricultural Technology, which were heavily attacked by the root-knot nematode, $M$. incognita. The nematodes were harvested according to method as described by Barker [16].

Inoculation of 6 months old pepper plant grown in a 21 pot containing sterilized soils, was conducted by pouring 10 $\mathrm{ml}$ of water containing 1000 nematode juveniles onto the soil surface. One week after the inoculation in which the nematodes infest roots of the pepper plants, $10 \mathrm{~g}$ of carbofuran $3 \%, 20 \mathrm{~g}$ of ground clove buds, or $60 \mathrm{~g}$ of dried betelvine leaves were applied evenly on the soil surface. Control consisted of pots without additional application. The experiments were performed with 10 replicates. Every pot was watered three times a week with about $350 \mathrm{ml}$ of fresh water. Two months after mulching the nematodes present on the roots of the treated plant were collected and counted. Collection was conducted according to the method described by Barker [16]. A $1 \mathrm{ml}$ of $40 \mathrm{ml}$ solution containing collected nematodes which had been homogenized using a magnetic stirrer was sampled using a micro pipette. The solution was put into the 1-ml Matsunami micro slide glass and the nematodes were counted using a stereo microscope under 100x magnification.

\subsection{Data Analysis}

The mortality rates of the nematodes in the exposure groups $\left(\mathrm{P}_{\mathrm{O}}\right)$ were corrected for mortality in the solvent controls $\left(\mathrm{P}_{\mathrm{C}}\right)$ using Abbott's formula: $\mathrm{P}_{\mathrm{T}}(\%)=\left[100 \mathrm{x}\left(\mathrm{P}_{\mathrm{O}}-\mathrm{P}_{\mathrm{C}}\right) /\right.$ $\mathrm{P}_{\mathrm{C}}$ ] [17]. The corrected mortality $\left(\mathrm{P}_{\mathrm{T}}\right)$ was plotted against the pesticide concentration and fitted using Slide Write Plus 6.1 (Advanced Graphics Software Inc.) to determine the $\mathrm{LC}_{20}$, $\mathrm{LC}_{50}$ and $\mathrm{LC}_{90}$ values. Because the $\log$ scale was used for plotting the data, the control data were included as a concentration being 100x lower than the lowest test compound concentration. The method of $95 \%$ LSD intervals was used for the means, and the SAS program for analysis of variance (ANOVA) and the least significant difference (LSD) test was used to compare the means of the bioassays. Data were transformed into $\sqrt{x}+0.5 .3$.

\section{RESULTS}

The yield of the extraction procedure varied between $4 \%$ (cashew, pressed) and 22\% (clove) (Table 1). In addition to clove also vetiver (14\%), patchouli $(12.4 \%)$ and castor bean $(12 \%)$ had relatively high yields. Density of the concentrated extract (expressed as $\mathrm{g} \mathrm{ml}^{-1}$ ) indicated a relatively oily content. The densities of the citrosa and the pyrethrum extracts were 0.68 and $0.75 \mathrm{~g} \mathrm{ml}^{-1}$ respectively, while the others had higher densities, which were between 0.86 and $1.06 \mathrm{~g} \mathrm{ml}^{-1}$.

In our laboratory study the average background mortality of the nematodes in the control treatment was about $4 \%$, indicating good starting conditions. Application of $5 \mathrm{mg}$ extract $\mathrm{ml}^{-1}$ exposure medium revealed that tobacco, clove and betelvine were highly toxic to the nematodes, killing more than $80 \%$ of the nematodes while the others gave quite low mortalities (Table 2). Based on these findings, these plant extracts were divided into 3 main groups i.e. highly toxic (>80\% mortality), consisting of clove, tobacco and betelvine, slightly toxic (10-20\% mortality) consisting of sweet flag, pyrethrum, and citronella and not toxic ( $<10 \%$ mortality) consisting of the rest of the extracts tested. The concentration of $31.5 \mathrm{mg}$ technical mixture $\mathrm{ml}^{-1}$ exposure medium of deltamethrin, carbosulfan, and chlorpyrifos killed 40, 73, and 
Table 2. Mortality of $M$. incognita and Lethal Concentrations after 24 hrs of Exposure to Botanical Extracts or Synthetic Pesticides in Aqueous Medium

\begin{tabular}{|c|c|c|c|c|}
\hline $\begin{array}{c}\text { Tested Compounds } \\
\text { Plant Extracts }^{\mathrm{c}}\end{array}$ & $(\text { Mortality }(\%) \pm \mathrm{SD})^{\mathrm{a}}$ & \multicolumn{3}{|c|}{ Lethal Concentrations $\left(\mathrm{mg} \mathrm{ml}^{-1}\right)^{\mathbf{b}}$} \\
\hline Clove & $98 \pm 2.3$ & 2.8 & 3.9 & 4.9 \\
\hline Tobacco & $94 \pm 3.1$ & 1.3 & 1.9 & 3.6 \\
\hline Betlevine & $83 \pm 1.2$ & 1.2 & 3.0 & 5.2 \\
\hline Pyrethrum & $13 \pm 3.0$ & 8.9 & $>19.2$ & $>19.2$ \\
\hline Citronella & $10 \pm 3.3$ & 5.7 & $>19.2$ & $>19.2$ \\
\hline Tuba root & $9 \pm 5.1$ & 8.6 & $>19.2$ & $>19.2$ \\
\hline Neem & $8 \pm 3.0$ & $>19.2$ & $>19.2$ & $>19.2$ \\
\hline Vetiver & $4 \pm 4.3$ & $>19.2$ & $>19.2$ & $>19.2$ \\
\hline Castor bean & $4 \pm 5.0$ & $>19.2$ & $>19.2$ & $>19.2$ \\
\hline Graviola & $4 \pm 5.0$ & $>19.2$ & $>19.2$ & $>19.2$ \\
\hline Patchouli & $4 \pm 5.6$ & $>19.2$ & $>19.2$ & $>19.2$ \\
\hline Lemongrass & $4 \pm 5.7$ & $>19.2$ & $>19.2$ & $>19.2$ \\
\hline Yam bean & $1 \pm 5.9$ & $>19.2$ & $>19.2$ & $>19.2$ \\
\hline Citrosa & $2 \pm 3.4$ & $>19.2$ & $>19.2$ & $>19.2$ \\
\hline
\end{tabular}

${ }^{\mathrm{a}}$ Pilot study, ${ }^{\mathrm{b}}$ Final experiment, ${ }^{\mathrm{c}}$ Tested in $5 \mathrm{mg} \mathrm{ml}^{-1}$, ${ }^{\mathrm{d}}$ Tested in $31.5 \mathrm{mg} \mathrm{ml}^{-1}$.

Note: In the pilot study only a single concentration was tested, while in the final experiments lethality was tested for 5 exposure concentrations to evaluate $\mathrm{LC}_{20}$, $\mathrm{LC}_{50}$, and $\mathrm{LC}_{90}$. Experiments were conducted in triplicates.

93\% of the treated nematodes, respectively (Table 2). Therefore, to find the $\mathrm{LC}_{50}$ values chlorpyrifos was further tested at $0,4,13,22$, and $31 \mathrm{mg}$ technical mixture $\mathrm{ml}^{-1}$ exposure medium, and the other two at $0,13,22,31$, and $40 \mathrm{mg}$ technical mixture $\mathrm{ml}^{-1}$ exposure medium.

The highly toxic group of plant extracts was further tested at concentrations of $0,1.2,2.4$, and $4.8 \mathrm{mg} \mathrm{ml}^{-1}$ exposure medium, while the other groups were tested at concentrations of $0,4.8,9.6$, and $19.2 \mathrm{mg} \mathrm{ml}^{-1}$ exposure medium. The extracts were not tested at a higher concentration as some of them (cashew, tuba root, and neem) did not mix adequately at these higher concentrations. In addition, these pesticides were not considered for possible future application as these would require great volumes of plant material, which would not result in a practical protocol for pesticide use. The results revealed that tobacco, clove and betelvine were highly toxic with $\mathrm{LC}_{50}$ values of $1.9-3.9 \mathrm{mg} \mathrm{ml}^{-1} \mathrm{ex}-$ posure medium. Sweet flag was moderately toxic with an $\mathrm{LC}_{50}$ of $11.3 \mathrm{mg} \mathrm{ml}^{-1}$ exposure medium. The $\mathrm{LC}_{50}$ of tuba root, citronella and pyrethrum were not reached, but their $\mathrm{LC}_{20}$ was $5.7-8.9 \mathrm{mg} \mathrm{ml}^{-1}$ exposure medium. The remaining 10 extracts were not toxic to the nematode as the $\mathrm{LC}_{20}$ was not reached (> $19.2 \mathrm{mg} \mathrm{ml}^{-1}$ exposure medium) (Table 2). Representative dose response graphs of extracts from each of these groups of plant extracts are given in Fig. (1). The synthetic pesticides chlorpyrifos and carbosulfan both fell in the slightly toxic group with an $\mathrm{LC}_{50}>19.2 \mathrm{mg} \mathrm{ml}^{-1}$ exposure medium and an $\mathrm{LC}_{20}$.of 8.7-12.7 $\mathrm{mg} \mathrm{ml}^{-1}$ exposure medium. Deltamethrin fell into the non-toxic groups with a $\mathrm{LC}_{20}>$ $19.2 \mathrm{mg} \mathrm{ml}^{-1}$. This lower toxicity of the synthetic technical pesticide mixtures compared to the plant extracts can also be seen from the dose response curves (Fig. 2).

When the dead nematodes were studied under the microscope it became apparent that they had either one of four very distinct shapes, namely: straight (I-shape), bent (banana-shape), sigmoid ( $\Sigma$-shape), or curly ( $\infty$-shape) (Table $\mathbf{3}$, Fig. 3). The dead nematodes from the control group mostly was straight (I shape) with only very few showing a bent 


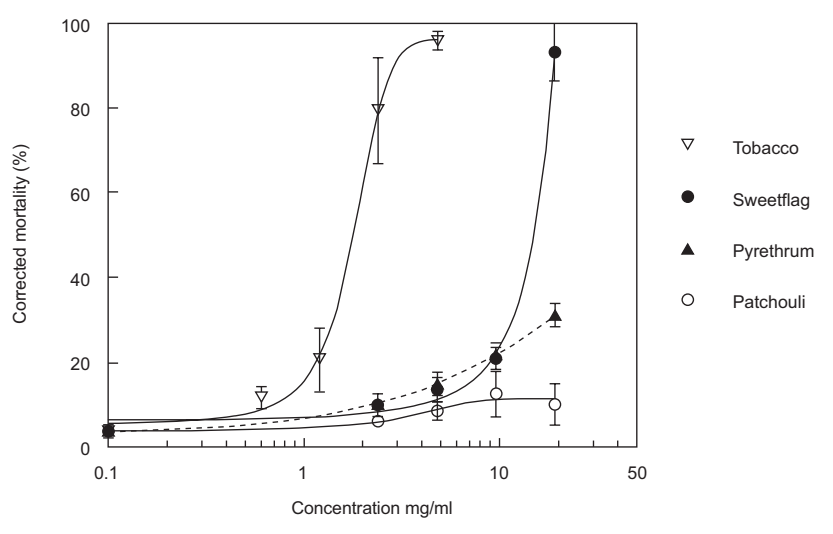

Fig. (1). Examples of plant extracts, which were highly, slightly and not acutely toxic to $M$. incognita. The concentration was expressed as mg extract $\mathrm{ml}^{-1}$ exposure medium presented on a log axis, mortality was corrected for control mortality using Abbot's formula, exposure was during $24 \mathrm{~h}$ in triplicate.

(banana) shape. The characteristic shape of nematodes killed by tobacco and castor bean was curly ( $\infty$-shapes) with some bent and sigmoid shapes, which was similar to those killed by the acetylcholine esterase inhibitors chlorpyrifos and carbosulfan. The appearances of the nematodes killed by other plant extracts mostly followed straight or bent shapes, simi-

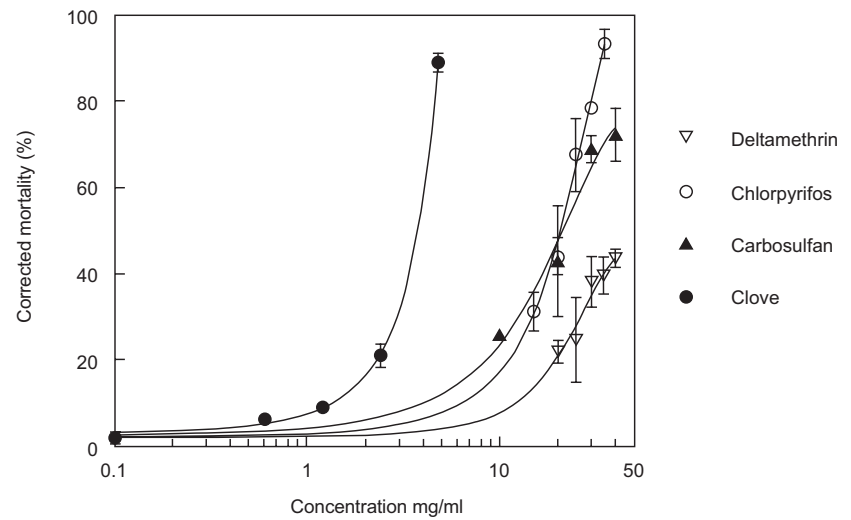

Fig. (2). Acute toxicity of three synthetic pesticides to root-knot nematode, $M$. incognita, compared to that of the plant extract, clove. The concentration of synthetic pesticides was expressed as $\mathrm{mg}$ technical mixture $\mathrm{ml}^{-1}$ exposure medium presented on a $\log$ axis, mortality was corrected for control mortality using Abbot's formula; exposure was during $24 \mathrm{~h}$ in triplicate.

lar to those killed by the pyrethroid deltamethrin. The mortality and these characteristics were tested for consistency with the highest concentrations, and all pesticides yielded exactly the same results.

Table 3. Relative Occurrence (\%) of Characteristic Shapes and Percentage of Relative Occurrence Among Dead Nematodes (M. incognita) after 24 hrs Exposure to the Highest Concentration of the Botanical Extracts or Synthetic Pesticides in Aqueous Medium. Number of Tested Nematodes is 150 Juveniles. The 4 Distinguished Shapes are shown in Fig. (3)

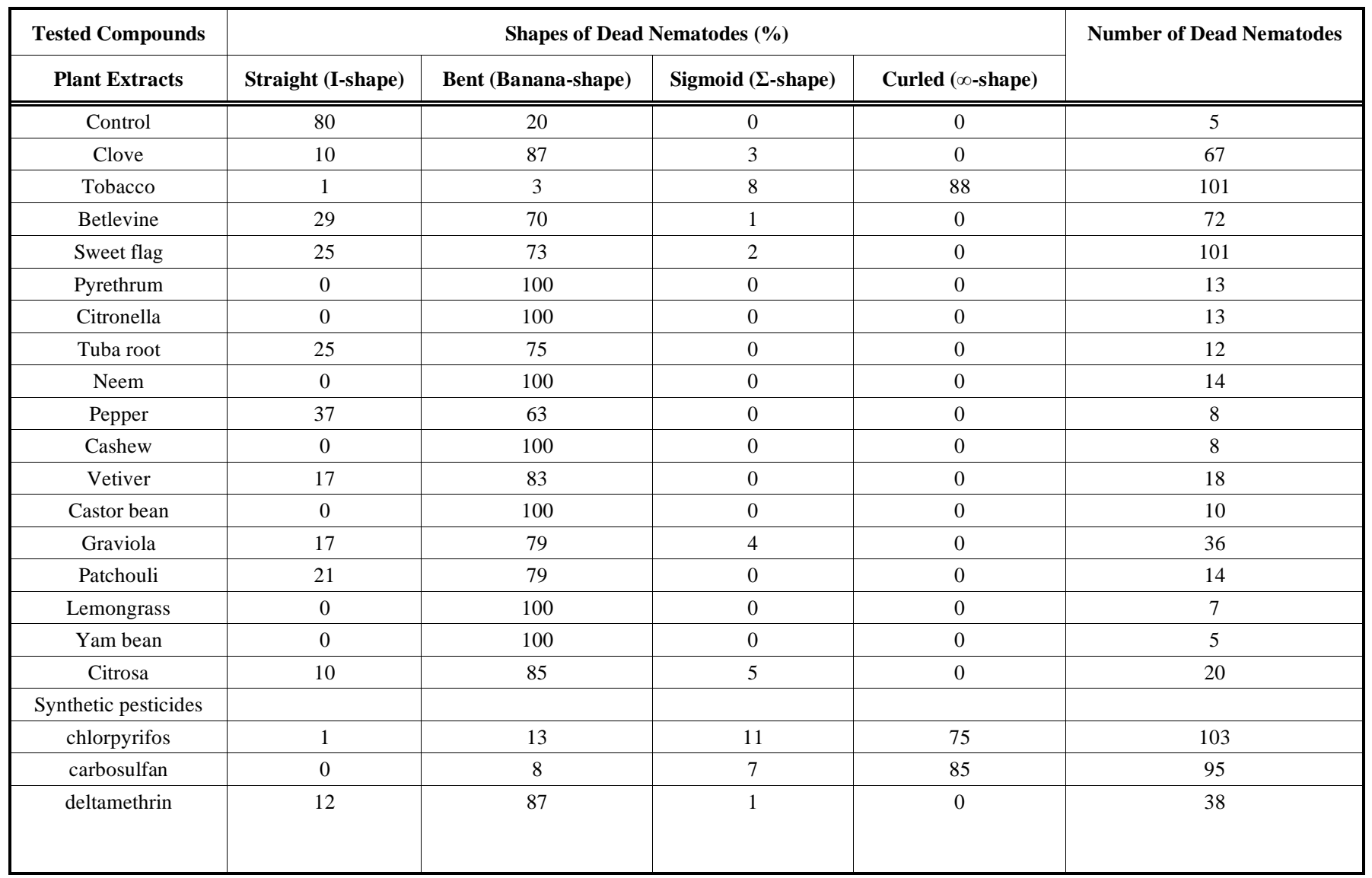



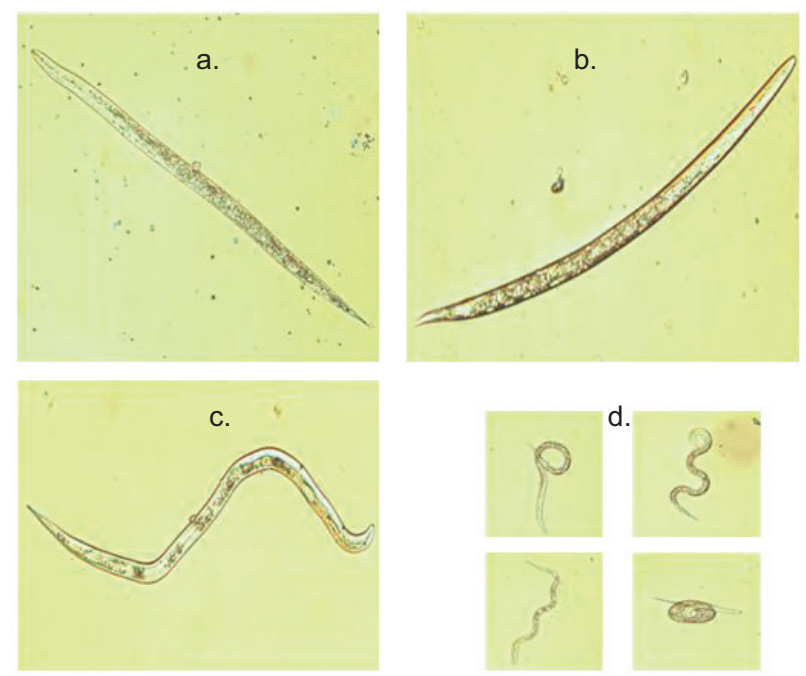

Fig. (3). Characteristic shapes of dead nematodes: a. straight (Ishape), b. bent (banana-shape), c. sigmoid ( $\Sigma$-shape), and d. curled $(\infty$-shape). See Table 3 for percentage relative occurrence of these shapes after exposure to the highest concentrations of the botanical and synthetic pesticides.

In the greenhouse experiments clove was 10 times more potent than betelvine in reducing the total number of nematodes in the roots after 2 months of a single application. The number of nematodes in the root treated with the clove bud differed insignificantly compared to the roots treated with the recommended synthetic pesticide, carbofuran. Although betelvine was able to reduce the infestation of the nematodes compared to control, this difference was not statistically significant. In addition, the number of infected plants treated with the clove bud was lower than that of the betelvine and control groups. There was no plant mortality among the clove and carbofuran treated plants. Meanwhile 1 and 3 plants died in the betelvine-treated and control groups respectively (Table 4).

\section{DISCUSSION AND CONCLUSION}

This study revealed that some plant extracts were highly toxic against nematodes in a laboratory exposure. One of these plants was also effective in controlling infestation of nematodes into roots of the pepper plants during a 2 months semi-field testing.
The in vivo laboratory study showed that tobacco, clove and betelvine, were highly toxic for the parasitic root-knot nematode, $M$. incognita with $\mathrm{LC}_{50}$ values of 1.9, 3.9, and 3.0 mg extract $\mathrm{ml}^{-1}$ exposure medium, respectively. Sweet flag was more moderately toxic $\left(\mathrm{LC}_{50}=11.3 \mathrm{mg}\right.$ extract $\mathrm{ml}^{-1}$ exposure medium). The later was still even more toxic than the tested concentrations of the three synthetic pesticides i.e. chlorpyrifos, carbosulfan and deltamethrin with $\mathrm{LC}_{50}$ values of $19.4,25.3$, and $>40 \mathrm{mg}$ technical mixture $\mathrm{ml}^{-1}$ exposure medium, respectively. This potent nematicidal action could be due to the active ingredient eugenol of clove oil, which has been shown to act as a potent nematicide [32]. An important active ingredient reported for sweetflag is $\beta$-asarone, which has also been reported to act as potent nematicide in banana plantation in India [21]. Clove and the sweetflag extracts have been reported to contain $88 \%$ eugenol [33] and $45.5 \% \beta$-asarone [34], respectively. Therefore, the $\mathrm{LC}_{50 \mathrm{~s}}$ of clove and sweetflag extracts would be equivalent to 3.4 and $5.2 \mathrm{mg}$ eugenol and $\beta$-asarone $\mathrm{ml}^{-1}$ solvent, respectively. Compared to the $\mathrm{LC}_{50}$ 's of chlorpyrifos, carbosulfan and deltamethrin of $19.4,25.3$, and $>40 \mathrm{mg}$ technical mixture $\mathrm{ml}^{-1}$ water are equivalent to $3.8,5.1$, and $>1 \mathrm{mg} \mathrm{ml}^{-1}$ solvent. The active ingredient eugenol of clove is more toxic against M.incognita than that of the tested synthetic pesticides.

The toxic potency of clove against $M$. incognita and $R a$ dopholus similes has been reported before by Mustika and Slamet [35], who found that on $1 \%$ concentration clove oil administered via aqueous medium effectively killed all directly exposed nematodes within 10 minutes after application. In addition, Meyer et al. [36] reported that volatiles from $5.0 \%$ clove oil reduced nematode egg hatching in water by $30 \%$, and decreased viability of hatched Juvenile (J2) of M. incognita by as much as $100 \%$.

This finding is very promising since farmers on Bangka Island indicate that currently there is no effective synthetic pesticide available to control this nematode in the field [9]. The ineffectiveness of the pesticides used against the nematodes such as fenthion, lambda cyhalothrin, carbofuran, and deltametrhin, may be the result of the low concentrations usually applied i.e. between $1-4 \mathrm{mg}$ technical mixture $\mathrm{ml}^{-1}$ water in combination with the limited availability of the solution for the buried nematodes. These concentrations normally are used to control the above ground insect pest species i.e. tinged bug, Dasynus piperis China, stem borer, Lophobaris piperis Marsh and bug, Diconocoris hewetti Dist [9]. Our findings showed that the synthetic pesticides chlorpyrifos and carbosulfan would be effective if they could reach the nematodes in a concentration of at least $30 \mathrm{mg}$ technical mixture $\mathrm{ml}^{-1}$ water, which is about 7-30 times

Table 4. The Number of Infected and Dead Plants and the Number Nematodes Presents 2 Months after a Single Application of Clove, Betelvine, and Carbofuran in a Greenhouse Experiment. The Plants were Experimentally Infected 7 Days Before Treatment; $\mathbf{n}=\mathbf{1 0}$

\begin{tabular}{|c|c|c|c|}
\hline Treatments & Infected Plants & \# of Dead Plants $^{\text {\# of Nematodes } \pm \text { SE per g Roots }}$ \\
\hline \hline Control & 10 & 3 & $335 \pm 69.9^{\mathrm{b}}$ \\
\hline Betelvine & 8 & 1 & $274 \pm 70.7^{\mathrm{b}}$ \\
\hline Clove & 5 & 0 & $23 \pm 9.3^{\mathrm{a}}$ \\
\hline Carbofuran & 3 & 0 & $5.3 \pm 5.1^{\mathrm{a}}$ \\
\hline
\end{tabular}

${ }^{*}$ Means in the same column followed by the same letter do not differ significantly $(\mathrm{P}>0.05)$ in the LSD test. 
higher than the concentration used by local farmers. Carbofuran was not tested in our study since it could not be diluted adequately in the solvent, even after $10 \mathrm{~min}$ of sonification, making it impossible to compare exposure concentrations.

The observed characteristic differences in shape of the nematodes killed by pesticide-exposure was an interesting finding that might be useful as an indication to analyze the major mode of toxic action of the plant extracts of usually very complex composition. Meanwhile, according to Akhtar and Mahmood [37] the nematicidal mode of action of plant materials still is not known. Our finding showed that the nematodes killed by the acetyl cholinesterase inhibitors chlorpyrifos and carbosulfan mostly had a curled shape (75$85 \%)$ while few of them had sigmoid (7-11\%) and bent (8$13 \%$ ) shapes.

In our bioassays the extract of tobacco also induced curled $(88 \%)$ and sigmoid $(8 \%)$ shapes. These shapes are similar to those of nematodes killed by the organophosphate and carbamate pesticides, which are known to have acetylcholine esterase inhibiting action. This finding is in line with the report of Nguyen et al. [38], who described that tobacco has acetylcholinesterase inhibiting effects in humans, as the neuromuscular junctions of nematodes were not fundamentally different, either structurally nor functionally, from the neuromuscular junctions of other animals [39] including mammals.

The pyrethroid pesticide deltamethrin and the extract of pyrethrum, known for its pyrethroid-like action, resulted in dead nematodes that never had curly shapes but were mostly bent (banana-shape) (87-100\%) and to some extent straight (I-shape) (0-13\%) or very few of them showing a sigmoid shape ( $\sum$-shape) $(0-1 \%)$. The results shown in table 3 suggested that the mechanisms of toxicity behind the curly shape were related to that of the sigmoid shape, as their occurrence was related and they might just represent a gradual difference in occurrence of the toxicity. Based on the shapes of the dead nematodes we suggest that most of the extracts tested had a pyrethroid-like effect on the central nervous system of the nematodes. However, further assays in higher concentration or longer exposure period would be helpful to validate this finding since the mortality induced by most of the botanical extracts still was very low. We did not have any explanation yet for the clear relationship between shapes of the dead nematode in relation to the pesticide exposure. During the experiment it was observed that about five min after exposure to organophosphate and carbamate pesticides and a tobacco extract, nematodes showed more active movement and most of them had formed curly shape and stayed stable until they died. On the other hand, those exposed by other treatments did not show specific shapes so soon. Their appearances were similar as those in control.

Although the tobacco extract is the most toxic against the nematodes, it is not the best candidate to be applied in practice because of its high toxicity for mammals including man ${ }^{40}$. The other two highly toxic plants, clove and betelvine, are more promising plants to be further developed into a botanical nematicide. Of these two, clove gives the highest extraction yield $(22.2 \%)$ followed by betelvine $(8.6 \%)$. The extraction yield of the less toxic sweet flag is only $6.5 \%$ (Table 1). The application of ethanol for the extraction of plant extract as carried out in this study is not suitable for the farmers be- cause it is too expensive for them while according to Zuskin et al. [41] high exposure of alcohol through inhalation often causes chronic obstructive lung disease. Therefore, easier and simpler preparation methods must be developed before a plant can be successfully introduced and applied as a botanical pesticide for the farmers. Two promising methods are application as an aqueous extract [42] and as an amendment of organic materials as mulch [43-45]. In our study we choose for testing clove and betelvine as a mulch because mulching is believed to help control plant parasitic nematodes, as nitrate and ammonical nitrogen accumulating during decomposition of organic matters are toxic to plant parasitic nematodes [46]. The effectiveness of mulching to reduce the population of the nematodes will be greatly enhanced when the mulch also contains toxic chemicals [47] such as the nematicidal compounds of clove. Amendment of organic plant materials also increases food sources which facilitates the population growth of bacterivorous nematodes (Rhabditidae and Cephalobidae), fungivorous nematodes [48] and predatory nematodes (Mononchidae) [49], which will also lower the population density of the plant parasitic nematodes through competition, antagonism or creating unfavorable conditions.

The greenhouse experiment revealed that mulch from clove bud was very potent in suppressing nematode infestation in pepper plants. After 2 months of single application clove significantly suppressed the population of nematodes in the pepper plant roots. The dosages of clove and betelvine used during the greenhouse experiment were based on the $\mathrm{LC}_{90}$ value of the laboratory bioassay, which was about $5 \mathrm{mg}$ extract $\mathrm{ml}^{-1}$ exposure medium. This value was equivalent to about $20 \mathrm{~g}$ clove buds and $60 \mathrm{~g}$ dried betelvine leaves based on extraction yields of 22.2 and $8.6 \%$ respectively. The dosage of carbofuran was $10 \mathrm{~g}$ which was $1 / 3$ of what would be recommended per plant in the field. This amount of carbofuran used was based on an assumption that the volume of the soil in the pot was $1 / 3$ of that in the field. The proposed dosage of clove for field application therefore is $60 \mathrm{~g}$ per plant.

Since clove is the $6^{\text {th }}$ major cultivated plant on Bangka Island [50], this plant material has a good prospect to be further developed as natural nematicide. Moreover, since the price of clove bud dropped from about $9 \mathrm{US}_{\mathrm{kg}}{ }^{-1}$ in 2001

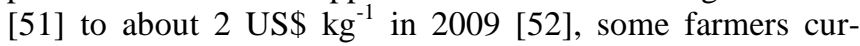
rently neglect their plantations and do not even harvest their plants [53]. Therefore, new additional uses of the clove bud as nematicide would be very welcome. Although application of $60 \mathrm{~g}$ clove bud per plant, with estimated costs equivalent to about 0.12 US\$, is about 4-fold more costly than the use of $30 \mathrm{~g}$ carbofuran per plant, with estimated costs equivalent to about 0.03 US $\$$, the use of clove mulch as a nematicide has a good prospect as it is environmentally friendly and can be locally produced. In addition it will induce plant production as the result of degradation of organic materials and suppress the development of root rot disease caused by Phytophthora palmivora [54] because clove contains eugenol, which acts as a potent fungicide [55].

To allow a successful introduction, practical information related to the use of plant materials to effectively control pests has to be developed and made available to the farmers. It is expected that application of clove, as a botanical pesti- 
cide will be adopted easily by local farmers on Bangka Island as in the past farmers in this region used plant materials as pesticides [9]. The results of the present study indicate that once a useful recipe is developed the use of clove can help to reduce the current intensive but not so effective use of synthetic pesticides against nematodes, and also the connected risk for human and environmental health.

\section{ACKNOWLEDGEMENTS}

The authors are grateful to the Head of the Indonesian Medicinal and Aromatic Crops Research Institute for providing many facilities throughout this study. We acknowledge the help of Mr. Ma'mun BSc, and Mr. Dedy Kustiwa with the extraction of the plant materials, and of $\mathrm{Mr}$. Endang $\mathrm{Su}-$ gandi and Mrs. Kurniati with the greenhouse experiment.

\section{REFERENCES}

[1] Siddiqui, Z. A.; Iqbal, A.; Mahmood, I. Effects of Pseudomonas fluorescens and fertilizers on the reproduction of Meloidogyne incognita and growth of tomato. Appl. Soil Ecol., 2001, 16(2), 179185.

[2] Anonymous. The Development of Pests, Diseases and Weeds. Annual Report of the Estate Crops Institute of the Bangka-Belitung Province; (Indonesian), 2004

[3] Davis, R. F.; May, O. L. Relationship between yield potential and percentage yield suppression caused by the southern root-knot nematode in cotton. Crop Sci., 2005, 45(6), 2312-2317.

[4] Khan, Z.; Kim, Y. H. A review on the role of predatory soil nematodes in the biological control of plant parasitic nematodes. Appl. Soil Ecol., 2007, 35(2), 370-379.

[5] Khan, Z.; Kim, Y. H.; Kim, S. G.; Kim, H. W. Observations on the suppression of root-knot nematode (Meloidogyne arenaria) on tomato by incorporation of cyanobacterial powder (Oscillatoria chlorina) into potting field soil. Bioresource Technol., 2007, 98(1), 6973.

[6] Okada, H.; Harada, H. Effects of tillage and fertilizer on nematode communities in a Japanese soybean field. Appl. Soil Ecol., 2007, 35(3), 582-598.

[7] Williamson, V. M.; Kumar, A. Nematode resistance in plants: The battle underground. Trends Genet., 2006, 22(7), 396-403.

[8] Browning, M.; Wallace, D. B.; Dawson, C.; Alm, S. R.; Amador, J. A. Potential of butyric acid for control of soil-borne fungal pathogens and nematodes affecting strawberries. Soil Biol. Biochem., 2006, 38(2), 401-404.

[9] Taniwiryono, W.D.; Brink, P. V. D.; Rietjens, I. M. C. M.; Murk, A. J. A case study in Bangka Island, Indonesia on the habits and consequences of pesticide use in black pepper plantations. J. Environ. Toxicol., 2007, 22(4), 405-414.

[10] Fernandez, C.; Rodriguez-Kabana, R.; Warrior, P.; Kloepper, J. W. Induced soil suppressiveness to a root-knot nematode species by a nematicide. Biol. Control, 2001, 22(2), 103-114.

[11] Javed, N.; Gowen, S. R.; Inam-ul-Haq, M.; Abdullah, K.; Shahina, F. Systemic and persistent effect of neem (Azadirachta indica) formulations against root-knot nematodes, Meloidogyne javanica and their storage life. Crop Protect., 2006, 26(7), 911-916.

[12] Ujvary, I. Pest Control Agents from Natural Products, Handbook of Pesticide Toxicology. $2^{\text {nd }}$ ed.; Academic Press: San Diego, 2001.

[13] Orme, S.; Kegley, S. PAN Pesticide Database, Pesticide Action Network. Available: http:www.pesticideinfo.org (Last visited): January $21^{\text {st }} \mathbf{2 0 0 7}$.

[14] European Food Safety Authority Conclusion Regarding the Peer Review of the Pesticide Risk Assessment of the Active Substance: Carbosulfan. Summary of the EFSA Scientific Report (2006) 91, 184, finalised: 28 July 2006. Available: http://www.efsa.europa.eu/etc/medialib/efsa/science/praper/conclusions/carbosulfan.Par.0008.File.dat/praper_concl_sr91_carbosulfan _summary_en.pdf (Last visited): May, $15^{\text {th }} \mathbf{2 0 0 7}$.

[15] Yuliani, S.; Rusli, S. Extraction of Botanical Pesticides. Indonesian Spice and Medicinal Crops Research Institute. Bogor, 2003; p. 17.

[16] Barker, K. R. Nematode extraction and bioassays. In An Advanced Treatise on Meloidogyne, Barker, K. R.; Carter, C. C.; Sasser, J. N., Eds. N.C. State Graphics: Raleigh, NC, 1985, Vol. 2, pp. 19-35.
[17] Collett, D. Modeling Binary Data. Chapman and Hall: London, 1991; p. 369.

[18] Park, I.-K.; Park, J.-Y.; Kim, K.-H.; Choi, K.-S.; Choi, I.-H.; Kim, C.-S.; Shin, S.-C. Nematicidal activity of plant essential oils and components from garlic (Allium sativum) and cinnamon (Cinnamomum verum) oils against the pine wood nematode (Bursaphelenchus xylophilus). Nematology, 2005, 7(5), 767-774.

[19] Akhtar, M. Utilisation of plant-origin waste materials for the control of plant-parasitic nematodes. Bioresource Technol., 1993, 46(3), 255-257.

[20] Mackeen, M. M.; Ali, A. M.; Abdullah, M. A.; Nasir, R. M.; Mat, N. B.; Razak, A. R.; Kawazu, K. Antinematodal activity of some Malaysian plant extracts against the pine wood nematode, Bursaphelenchus xylophilus. Pest Manage. Sci., 1999, 51(2), 165-170.

[21] Waele, D. D.; Davide, R. G. The root-knot nematode of banana. Musa Pest Factsheet No. 3. Available: http://bananas.bioversityinternational.org/files/files/pdf/publication s/pest3_en.pdf (Last visited): April $26^{\text {th }} \mathbf{2 0 0 7}$.

[22] Perez, M. P.; Navas-Cortes, J. A.; Pascual-Villalobos, M. J.; Castillo, P. Nematicidal activity of essential oils and organic amendments from Asteraceae against root-knot nematodes. Plant Pathol., 2003, 52(3), 395-401.

[23] Varma, J.; Dubey, N. K. Prospectives of botanical and microbial products as pesticides of tomorrow. Available: http://www.ias.ac.in/currsci/jan25/articles22.htm (Last visited): April $26^{\text {th }} \mathbf{2 0 0 7}$.

[24] Feng, Y.-H. W, Plant extracts of several plant pathogenic nematodes kill line screening activity. Huazhong Agric. Univ. J., 2001, 3, 235-238.

[25] Akhtar, M. Biological control of plant-parasitic nematodes by neem products in agricultural soil. Appl. Soil Ecol., 1998, 7(3), 219-223.

[26] Tiyagi, S. A.; Alam, M. M. Efficacy of oil-seed cakes against plant-parasitic nematodes and soil-inhabiting fungi on mungbean and chickpea. Bioresource Technol., 1995, 51(2-3), 233-239.

[27] Abid, M. Studies on the control of root-knot nematodes (Meloidogyne spp.) with botanical toxicants. University of Karachi, Karachi, 1996. Available: http://eprints.hec.gov.pk/1355/01/1059.html .htm (Last visited): August $12^{\text {nd }} \mathbf{2 0 0 8}$.

[28] Adegbite, A. A.; Adesiyan, S. O. Root extracts of plants to control root-knot nematode on edible soybean. World J. Agric. Sci., 2005, 1(1), 18-21.

[29] Onifade, A. K.; Fawole, B. Effect of some plant extracts on the pathogenicity of Meloidogyne incognita on cowpea. Global J. Pure Appl. Sci.,1996, 2, 9-15.

[30] International Centre for Research in Agroforestry Trees in Agricultural systems. Available: http://www.echotech.org/technical/az/ aztext/azch4tre.htm\#Table (Last visited) May $10^{\text {th }}, \mathbf{2 0 0 7}$.

[31] Pandey, R.; Kalra, A.; Tandon, S.; Mehrotra, N.; Singh, H. N.; Kumar, S. essential oils as potent source of nematicidal compounds. J. Phytopathol., 2000, 148(7-8), 501-502.

[32] Tsao, R.; Yu, Q. Nematicidal activity of monoterpenoid compounds against economically important nematodes in agriculture. $J$. Essential Oil Res., 2000, 12(3), 350-354

[33] Lane, B. W.; Ellenhorn, M. J.; Hulbert, T. V.; McCarron, M. Clove oil ingestion in an infant. Human. Exp. Toxicol., 1991, 10(4), $291-$ 4.

[34] Venskutonis, P. R.; Dagilyte, A. Composition of essential oil of sweet flag (Acorus calamus L.) leaves at different growing phases. J. Essential Oil Res., 2003, Sept/Oct. Available: http://findarticles. com/p/articles/mi_qa4091/is_200309/ai_n9281650 (Last visited): March $2^{\text {nd }} \mathbf{2 0 0 8}$.

[35] Mustika, I.; Slamet, A. R. In Efication of Clove Products and Other Botanical Plants Against Nematodes Attacking Black Pepper, Conference on Results of the experiments in order to utilize botanical pesticides. (Indonesian), 1994; Research Institute for Spice and Medicinal Crops, Bogor, Indonesia, 1994

[36] Meyer, S. L.; Lakshman, D. K.; Zasada, I. A.; Vinyard, B. T.; Chitwood, D. J. Dose-response effects of clove oil from Syzygium aromaticum on the root-knot nematode Meloidogyne incognita. Pest Manage. Sci., 2008, 64, 223-229.

[37] Akhtar, M.; Mahmood, I. Potentiality of phytochemicals in nematode control: A review. Bioresource Technol., 1994, 48(3), 189 201.

[38] Nguyen, V. T.; Hall, L. L.; Gallacher, G.; Ndoye, A.; Jolkovsky, D. L.; Webber, R. J.; Buchli, R.; Grando, S. A. Choline acetyltransferase, acetylcholinesterase, and nicotinic acetylcholine receptors 
of human gingival and esophageal epithelia. J. Dent. Res., 2000, 79, 939-949.

[39] Debell, J. T. A long look at neuromuscular junctions in nematodes. Q.Y. Rev. Biol., 1965, 40(3), 233-251.

[40] Isman, M. B. Problems and opportunities for the commercialization of botanical insecticides. In Biopesticides of Plant Origin, Regnault-Roger, C.; Philogène, B. J. R.; Vincent, C. Eds. Lavoisier: Paris, 2005.

[41] Zuskin, E.; Bouhuys, A.; Saric, M. Lung function changes by ethanol inhalation. Clin. Allergy, 1981, 11, 243-248.

[42] Begum, Z.; Shaukat, S. S.; Siddiqui, I. A. Suppression of Meloidogyne javanica by Conyza canadensis, Blumea obliqua, Amaranthus viridis and Eclipta prostrata. Plant Pathol. J., 2003, 2(3), 174180.

[43] Wang, K. H.; McSorley, R.; Marshall, A. J.; Gallaher, R. N. Nematode community changes associated with decomposition of Crotalaria juncea amendment in litterbags. Appl. Soil Ecol., 2004, 27(1), 31-45.

[44] Akhtar, M.; Malik, A. Roles of organic soil amendments and soil organisms in the biological control of plant-parasitic nematodes: a review. Bioresource Technol., 2000, 74(1), 35-47.

[45] Nahar, M. S.; Grewal, P. S.; Miller, S. A.; Stinner, D.; Stinner, B. R.; Kleinhenz, M. D.; Wszelaki, A.; Doohan, D. Differential effects of raw and composted manure on nematode community, and its indicative value for soil microbial, physical and chemical properties. Appl. Soil Ecol., 2006, 34(2-3), 140-151.

[46] Mian, I. H.; Rodriguez-Kabana, R. Soil amendments with oil cakes and chicken litter for control of Meloidogyne arenaria. Nematropica, 1982, 12(2), 205-220.

[47] Rodriguez-Kabana, R.; Morgan-Jones, G.; Chet, I. Biological control of plant nematodes: soil amendments and microbial antagonists. Plant Soil, 1987, 10, 237-247.
[48] Forge, T. A.; Hogue, E.; Neilsen, G.; Neilsen, D. Effects of organic mulches on soil microfauna in the root zone of apple: implications for nutrient fluxes and functional diversity of the soil food web. Appl. Soil Ecol., 2003, 22(1), 39-54.

[49] Yeates, G. W.; Wardle, D. A.; Watson, R. N. Responses of soil nematode populations, community structure, diversity and temporal variability to agricultural intensification over a seven-year period. Soil Biol. Biochem., 1999, 31(12), 1721-1733.

[50] Disbun-Propinsi-Bangka-Belitung The Development of Pests, Diseases and Weeds. Annual Report of the province of BangkaBelitung; Indonesian, 2004.

[51] Hermawan, D. Price of clove increased, National Income decreased. Tempo Interaktif. (Indonesian). 2001. Available: http://www.tempointeraktif.com/hg/ekbis/2001/03/09/brk,2001030 9-38,id.html (Last cited): February, $13^{\text {th }} 2009$.

[52] Anonymous, Rain, price of clove is decreasing. Radar Jogya. Indonesian. 2009. Available: http://www.jawapos.com/radar/index. php?act=detail\&rid=64993 (Last visited): February, $12^{\text {nd }} 2009$.

[53] Sinaro, S. D. Price of clove decreases farmers do not want to grow the plant Sinar Harapan. Indonesian. 2003. Available: http://www.sinarharapan.co.id/ekonomi/usaha/2003/0830/ukm3. html (Last visited): February $12^{\text {nd }} \mathbf{2 0 0 9}$.

[54] Mahon, P. M.; Purwantara, A. Major Crops Affected by Phytophthora, ACIAR Monograph 114. Available: http://www.aciar. gov.au/web.nsf/att/JFRN-6BN9E3/\$file/mn114-part2.pdf (Last cited): July 16th, 2007.

[55] Serrano, M.; Martinez-Romero, D.; Castillo, S.; Guillen, F.; Valero, D. The use of natural antifungal compounds improves the beneficial effect of MAP in sweet cherry storage. Innovative Food Sci. Emerg. Technol., 2005, 6, 115-123.

(C) Wiratno et al.; Licensee Bentham Open.

This is an open access article licensed under the terms of the Creative Commons Attribution Non-Commercial License (http://creativecommons.org/licenses/by-nc/3.0/) which permits unrestricted, non-commercial use, distribution and reproduction in any medium, provided the work is properly cited. 